\title{
Self-Reported Addiction to Pornography in a Nationally Representative Sample: The Role of Use Habits, Religiousness, and Moral Incongruence
}

\author{
Joshua B. Grubbs, ${ }^{1}$ Shane W. Kraus, ${ }^{2}$ and Samuel L. Perry ${ }^{3}$
}

Background and Aims: Despite controversies regarding its existence as a legitimate mental health condition, self-reports of pornography addiction seem to occur regularly. In the United States, prior works using various sampling techniques, such as undergraduate samples and online convenience samples, have consistently demonstrated that some pornography users report feeling dysregulated or out of control in their use. Even so, there has been very little work in U.S. nationally representative samples to examine self-reported pornography addiction.

Methods: The present study sought to examine self-reported pornography addiction in a U.S. nationally representative sample of adult internet users $(\mathrm{N}=2,075)$.

Results: Results indicated that most participants had viewed pornography within their lifetimes $(\mathrm{n}=1,461)$, with just over half reporting some use in the past year $(n=1,056)$. Moreover, roughly $11 \%$ of men and $3 \%$ of women reported some agreement with the statement "I am addicted to pornography." Across all participants, such feelings were most strongly associated with male gender, younger age, greater religiousness, greater moral incongruence regarding pornography use, and greater use of pornography.

Discussion and Conclusions: Collectively, these findings are consistent with prior works that have noted that self-reported pornography addiction is a complex phenomenon that is predicted by both objective behavior and subjective moral evaluations of that behavior.

Pornography use is an immensely common behavior pattern in the developed world, with some U.S. studies reporting that up to $70 \%$ of men and $40 \%$ have used pornography within the past year (Regnerus, Gordon, \& Price, 2016) and some Australian studies reporting similar rates $(76 \%$ of men and $41 \%$ of women within the past year; Rissel et al., 2017). Even so, pornography use is controversial, with various academic sources claiming that such use is likely to have negative effects (Hilton Jr., 2013), likely to have positive effects (Ley, Prause, \& Finn, 2014), or likely to have mixed effects (Hald \& Malamuth, 2008). Of particular focus in such controversies has been the purported propensity of some pornography users to become addicted or compulsive in their use (for reviews, see: Duffy, Dawson, \& das Nair, 2016; Williams, 2017).

Historically, there has been no psychiatric diagnosis that would include the notion of pornography addiction. However, the ICD-11 has included a diagnosis of compulsive sexual behaviour disorder (Kraus et al., 2018; World Health Organization, 2018), which may subsume the notion of addictive or compulsive use of pornography (Kraus et al., 2018). The premise of this diagnosis is highly controversial, fueling intense critical commentary in psychiatry and psychology more generally (Humphreys, 2018; Kraus, Voon, \& Potenza, 2016). Even so, a number of people are willing to self-identify as feeling addicted to pornography, despite the unsettled science on the issue (Duffy et al., 2016). In short, a number of studies support the idea that some people endorse self-reported pornography addiction (Grubbs, Exline, Pargament, Hook, \& Carlisle, 2015; Grubbs, Wilt, Exline, Pargament, \& Kraus, 2018). Interestingly, a number of prior studies have found that the strongest predictors of self-

\footnotetext{
${ }^{1}$ Bowling Green State University

${ }^{2}$ Dept. of Veterans Affairs, VISN 1 New England MIRECC, Bedford VAMC

${ }^{3}$ University of Oklahoma

Declaration of Interests: None.

Correspondence concerning this pre-print should be addressed to Joshua B. Grubbs, Ph.D., Department of Psychology, Bowling Green State University, Bowling Green, OH, 43403.

Email: GrubbsJ@BGSU.edu
} 
reported pornography addiction, particularly in non-clinical populations, are religiousness and moral incongruence regarding pornography use-described as a discrepancy between beliefs about pornography use (i.e., that it is wrong) and pornography use behaviors — rather than objective behavior or dysregulation (Grubbs et al., 2015; Grubbs, Wilt, et al., 2018; Leonhardt, Willoughby, \& Young-Petersen, 2018). Moreover, the diagnostic criteria for CSBD explicitly note that moral judgments or religious beliefs cannot be the driving factors behind self-reported problems of excessive sexual behavior (Kraus et al., 2018).

Collectively, these trends illustrate that there may be important differences between true behavioral dysregulation and self-perceptions regarding pornography use (for reviews, see: Grubbs \& Perry, 2018; Grubbs, Perry, Wilt, \& Reid, 2018). Yet, most studies examining links between religiousness, moral incongruence, and self-reported pornography addiction have relied on limited sampling methods (e.g., undergraduate samples, Mechanical Turk; with the notable exception of Rissel et al., 2017, which examined pornography use and selfreported addiction in an Australian national sample). Such samples, although useful for initial inquiries, are not adequate to fully establish the scope of the relationships between pornography use, religiousness, moral incongruence, and self-reported addiction. More to the point, to date, there have been no U.S. nationally representative examinations of self-reported addiction to pornography.

Given such background, the purpose of the present work was multi-faceted. Primarily, we sought to establish U.S. nationally representative statistics for pornography use and self-reported pornography addiction. Additionally, we sought to address sampling limitations of past works that examined selfreported addiction to pornography, moral incongruence, and religiousness by examining these constructs in a cross-sectional U.S. nationally representative sample.

Broadly speaking, we expected to find that pornography use rates would be roughly comparable to prior estimates (e.g., $46 \%$ of men and $16 \%$ of women reporting use within the past week). We further expected to find that self-reported pornography addiction would be endorsed at much lower rates, likely occurring at rates that would be comparable to other behavioral addictions (e.g., 3\%-7\%) and prior national studies of self-reported addiction in Australia (e.g., 1\%-3\%, Rissel et al., 2017). Finally, consistent with previously referenced literature (Grubbs et al., 2015; Grubbs, Wilt, et al., 2018), we expected to find that moral incongruence, religiousness, and pornography use frequency would all emerge as distinct predictors of self-reported addiction to pornography.

\section{Methods}

Via Qualtrics Omnibus service, we recruited a U.S. nationally representative (based on 2010 census norms for age, gender, race, ethnicity, income, and U.S. Census region), cross-sectional study of adult internet users ( $N=2,075 ; 51 \%$ women $[n=1059], 49 \%$ men $\left.[n=1,016] ; M_{a g e}=44.8, S D=16.7\right)$. Analyses were limited to adults who acknowledged a lifetime history of ever viewing pornography $(N=1,461$, 59\% men; 74\% White/Caucasian; 11\%

Black/African-American; 10\% Hispanic/Latinx; 2\% Asian/Pacific-Islander; 3\% other; Census Region: Northeast 19\%, Midwest 23\%, West 21\%, South 37\%). Lifetime history of pornography viewing was assessed via an affirmative response to the following question: "In your lifetime, have you ever viewed pornography?" Consistent with current recommendations (e.g., Short, Black, Smith, Wetterneck, \& Wells, 2012), we provided a custom (i.e., developed by the authors) definition of pornography for participants, noting that: "Pornography refers to any sexually explicit films, video clips or pictures displaying the genital area, which intends to sexually arouse the viewer; this may be seen on the internet, in a magazine, in a book, or on television."

Unless otherwise noted, all measures were on a scale of 1 (Strongly Disagree) to 7 (Strongly Agree). 
Self-reported pornography related problems were measured using three face-valid single item, as well as the mean of three items $(a=.81)$. These three items were developed to represent one of the subscales of the CyberPornography Use Inventory-9, with slight refinements for readability: Access Efforts ("I have put off things I needed to do in order to view pornography"), Perceived Compulsivity ("I am addicted to pornography"), and Emotional Distress ("I feel depressed after viewing pornography," Grubbs et al., 2015). These three items were selected as they briefly assess cognitive (Perceived Compulsivity), behavioral (Access Efforts), and emotional (Emotional Distress) aspects of problematic pornography use.

Moral incongruence regarding pornography use was assessed via one item that was administered to pornography users ("I believe that pornography use is morally wrong"). As has been noted in prior works (Perry, 2017; Perry \& Whitehead, 2018), moral disapproval of pornography use among pornography users implies moral incongruence regarding use.

Pornography use was measured via two items: a 12-month frequency of use measure ranging from 1 (never) to 8 (more than once per day) and a free-response estimate of minutes spent viewing pornography per day.

Religiousness was assessed via the mean of three items generated for this study (e.g., "I attend religious services regularly," "Being religious is important to me," and "I consider myself religious," $a=.92$ ).

All analyses were conducted in the $p s y c h$ package for R Statistical Software (Revelle, 2014). Descriptive statistics for all scales are reported in Table 1. Item response distributions for key variables are available in Table 2. Our primary outcomes were measures of selfreported pornography related problems (either the single items or the aggregate scale), all of which were subject to cross-sectional correlations (see Table 1) and hierarchical, multivariable regressions (see Table 3 ) examining the unique variance in self-reported addiction accounted for by (Model 2) religiousness and (Model 3) moral incongruence, above and beyond a series of variables entered in Model 1 (age, gender, pornography use frequency, and pornography use daily average). Across analyses, Holmadjusted test statistics were used when evaluating statistical significance in order to correct for increased error due to multiple comparisons (Revelle, 2014).

\section{Ethics}

Prior to data collection, the methods and measures for this study, as well as the study hypotheses, were pre-registered via the Open Science Framework (https://osf.io/nxywf/). The methods and materials for this study were approved by the Institutional Review Board at the first author's institution. All participants completed an informed consent prior to their participation in the study.

\section{Results}

We found statistically distinguishable differences by gender (See Table 2) for all variables, except emotional distress and moral incongruence. Among those who self-reported pornography use, men reported greater levels of use, self-reported compulsivity, and selfreported access efforts.

Across correlations (Table 1), all included variables (religiousness, moral incongruence, age, gender, pornography use frequency, and average daily pornography use) emerged as associates of self-reported addiction, with religiousness, moral incongruence, pornography use frequency, and average daily use of pornography all emerging as positive associates of self-reported addiction, and age emerging as a negative associate of selfreported addiction. Moving further, in regression analyses (Table 3), all key variables emerged as predictors of self-reported addiction and access efforts, with moral incongruence and religiousness accounting for substantial amounts of variance in self-reported addiction in each step of the regression.

\section{Discussion}

At the outset of this work, we sought to examine U.S. national rates for pornography 
use and self-reported pornography addiction, as well as test the relationships between pornography use, religiousness, moral incongruence, and self-reported pornography addiction. To accomplish this end, we conducted a nationally-representative study of adults in the U.S. Across our results, our hypotheses were generally supported.

Regarding pornography use frequency, our findings are roughly consistent with Regnerus and colleagues' (2016) work that also reported on U.S. nationally representative statistics, which found that $46 \%$ of men and $16 \%$ of women report intentional pornography use within the past week. Although we note that Regnerus and colleagues' findings more closely match our findings regarding monthly use (e.g., 47\% for men and 16\% for women in the present study, compared to $46 \%$ and $16 \%$ respectively in Regnerus et al., 2016), there were key methodological differences in how we asked about pornography use in comparison to that prior work. Specifically, we asked about pornography use frequency (see measures above), whereas Regnerus and colleagues reported data asking about most recent pornography use (e.g., "When did you last intentionally look at pornography?"). In any case, our results, taken in conjunction with past findings, suggest that pornography use on a monthly-or-greater frequency is common among men and not uncommon among women.

Regarding self-reported addiction, responses to the item "I am addicted to pornography" indicated that some level of agreement with that item was not altogether uncommon. Although such self-reports are not linked to diagnostic standards of any sort, our findings indicate that, in the U.S. population, some level of self-reported pornography addiction was somewhat more common than we had hypothesized, with up to $11 \%$ of men agreeing at least somewhat and up to $3 \%$ of men agreeing strongly with the statement. Rates were much lower among women, with only $3 \%$ agreeing with that statement at least somewhat and only $1 \%$ agreeing strongly. Strong agreement rates were comparable to rates of users in Australia who self-identified as addicted to pornography (e.g., 3\% of Men and $1 \%$ of Women; Rissel et al., 2017, compared to $3 \%$ of men and $1 \%$ of women presently)

Finally, we examined how pornography use, religiousness, and moral incongruence might predict self-reported addiction to pornography. We were specifically interested in testing the unique contributions of religiousness and moral-incongruence to self-reported addiction. Using individual items (one of which assessed perceived compulsivity) and the aggregate of those items, we found that younger age, male gender, greater pornography use, greater religiousness, and greater moral incongruence were associated with higher reports of addiction. We also noted that the individual contributions of both moral incongruence (Step 3 of our regressions) and religiousness (Step 2 of our regressions) to selfreported addiction was quite substantial. This extends and strongly supports the model of Pornography Problems due to Moral Incongruence put forth in recent literature (Grubbs \& Perry, 2018; Grubbs, Perry, et al., 2018). By extending prior works to a U.S. sample, these findings contribute to the body of literature that now very strongly suggests that religiousness and moral disapproval are important factors in determining self-reported pornography addiction in non-clinical samples.

Finally, we would note that the results of our survey, though important, should be interpreted with caution. Our findings were correlational in nature. Although the findings of the present work are cross-sectional, given that they are consistent with recently published longitudinal findings (Grubbs, Wilt, et al., 2018) and theoretical models of moral incongruence (Grubbs \& Perry, 2018; Grubbs, Perry, et al., 2018), it is not unreasonable to speculate that they are directional in nature. Even so, future longitudinal, nationally-representative studies are needed. Additionally, our study relied on face-valid, brief, self-report measures throughout. Future work in similar samples with more comprehensive assessments are also

\footnotetext{
${ }^{* *}$ This manuscript is an author pre-print of the same published at The Journal Of Behavioral Addictions. ${ }^{* *}$
} 
needed, particularly as assessment becomes more precise with regards to the new compulsive sexual behaviour disorder diagnosis in the ICD-11. We would also note that, due to the brevity of this survey and time constraints associated with nationally representative works, we did not assess many other variables (e.g., impulsivity, compulsive sexuality more generally) that might mitigate or moderate the relationships we have described herein. We would also note that we only assessed these constructs among internet using adults in the U.S., and as such, our findings might not generalize to people who consume pornography via other media forms (e.g., magazines, DVDs, Cable television) or noninternet users.

\section{Conclusions}

Given recently intensified debates around the correct classification, diagnosis, and treatment of compulsive sexuality and the inclusion compulsive sexual behavior disorder in the ICD-11, these findings bear direct implications for both practice and research. Pornography use is common in the U.S., with large subsets of both men and women using frequently. Similarly, self-reported feelings of addiction to pornography are not uncommon. Whereas other types of addictive behavior (e.g., substance abuse or gambling disorder) are primarily determined by behavior, self-reported pornography addiction and, perhaps, compulsive sexuality more generally are more complex. Personal morality and religiousness also seem to shape interpretations of personal behavior, which should be considered by clinicians and researchers when interacting with patients expressing self-reported problems associated with pornography use and/or selfreported feelings of addiction.

\section{References}

Duffy, A., Dawson, D. L., \& das Nair, R. (2016). Pornography addiction in adults: A systematic review of definitions and reported impact. The Journal of Sexual Medicine, 13, 760-777. https://doi.org/10.1016/j.jsxm.2016.03 .002

Grubbs, J. B., Exline, J. J., Pargament, K. I., Hook, J. N., \& Carlisle, R. D. (2015). Transgression as addiction: Religiosity and moral disapproval as predictors of perceived addiction to pornography. Archives of Sexual Behavior, 44, 125-136. https://doi.org/10.1007/s10508-0130257-z

Grubbs, J. B., \& Perry, S. L. (2018). Moral Incongruence and Pornography Use: A Critical Review and Integration. The Journal of Sex Research, 1-9. https://doi.org/10.1080/00224499.201 8.1427204

Grubbs, J. B., Perry, S. L., Wilt, J. A., \& Reid, R. C. (2018). Pornography Problems Due to Moral Incongruence: An Integrative Model with a Systematic Review and Meta-Analysis. Archives of Sexual Behavior. https://doi.org/10.1007/s10508-0181248-x

Grubbs, J. B., Wilt, J. A., Exline, J. J., Pargament, K. I., \& Kraus, S. W. (2018). Moral disapproval and perceived addiction to internet pornography: A longitudinal examination. Addiction, 113, 496-506. https://doi.org/10.1111/add.14007

Hald, G. M., \& Malamuth, N. M. (2008). SelfPerceived Effects of Pornography Consumption. Archives of Sexual Behavior, 37, 614-625. https://doi.org/10.1007/s10508-0079212-1

Hilton Jr., D. L. (2013). Pornography addiction - a supranormal stimulus considered in the context of neuroplasticity. Socioaffective Neuroscience \& Psychology, 3, 20767. https://doi.org/10.3402/snp.v3i0.2076 7

Humphreys, K. (2018). Of moral judgments and sexual addictions. Addiction, 113, 387-388. https://doi.org/10.1111/add.14066

\footnotetext{
**This manuscript is an author pre-print of the same published at The Journal Of Behavioral Addictions. **
} 
Kraus, S. W., Krueger, R. B., Briken, P., First, M. B., Stein, D. J., Kaplan, M. S., ... Reed, G. M. (2018). Compulsive sexual behaviour disorder in the ICD-11. World Psychiatry, 17, 109-110. https://doi.org/10.1002/wps.20499

Kraus, S. W., Voon, V., \& Potenza, M. N. (2016). Should compulsive sexual behavior be considered an addiction? Addiction, 111, 2097-2106. https://doi.org/10.1111/add.13297

Leonhardt, N. D., Willoughby, B. J., \& YoungPetersen, B. (2018). Damaged goods: Perception of pornography addiction as a mediator between religiosity and relationship anxiety surrounding pornography use. Journal of Sex Research, 55, 357-368.

https://doi.org/10.1080/00224499.201 7.1295013

Ley, D. J., Prause, N., \& Finn, P. (2014). The emperor has no clothes: A review of the 'pornography addiction' model. Current Sexual Health Reports, 6, 94-105. https://doi.org/10.1007/s11930-0140016-8

Perry, S. L. (2017). Pornography use and depressive symptoms: Examining the role of moral incongruence. Society and Mental Health, 2156869317728373. https://doi.org/10.1177/215686931772 8373

Perry, S. L., \& Whitehead, A. L. (2018). Only bad for believers? Religion, pornography use, and sexual satisfaction among American men. Journal of Sex Research. https://doi.org/10.1080/00224499.201 7.1423017

Regnerus, M., Gordon, D., \& Price, J. (2016). Documenting pornography use in America: a comparative analysis of methodological approaches. The Journal of Sex Research, 53, 873-881.

Revelle, W. (2014). psych: Procedures for psychological, psychometric, and personality research. Northwestern University, Evanston, Illinois, 165.
Rissel, C., Richters, J., Visser, R. O. de, McKee, A., Yeung, A., \& Caruana, T. (2017). A profile of pornography users in australia: Findings from the second australian study of health and relationships. The Journal of Sex Research, 54, 227-240. https://doi.org/10.1080/00224499.201 6.1191597

Short, M. B., Black, L., Smith, A. H., Wetterneck, C. T., \& Wells, D. E. (2012). A review of internet pornography use research: Methodology and content from the past 10 years. Cyberpsychology, Behavior, and Social Networking, 15, 13-23. https://doi.org/10.1089/cyber.2010.04 77

Williams, D. J. (2017). The framing of frequent sexual behavior and/or pornography viewing as addiction: Some concerns for social work. Journal of Social Work, 17, 616-623. https://doi.org/10.1177/146801731664 4701

World Health Organization. (2018). ICD-11. Retrieved June 29, 2018, from https://icd.who.int/ 
Grubbs et al., (2018); Journal of Behavioral Addictions, DOI: 10.1556/2006.7.2018.134

Table 1

Pearson Correlations Between Included Measures

\begin{tabular}{|c|c|c|c|c|c|c|c|c|c|c|c|c|}
\hline & $\mathbf{M}$ & SD & 1 & 2 & 3 & 4 & 5 & 6 & 7 & 8 & 9 & 10 \\
\hline 1. Age & 44.8 & 16.7 & - & .22 & -.22 & -.127 & -.168 & -.182 & -.109 & -.178 & .034 & .045 \\
\hline 2. Male Gender & - & - & & - & .313 & .05 & .186 & .175 & .041 & .154 & -.004 & -.045 \\
\hline 3. Frequency of Pornography Use & 3.69 & 2.41 & & & - & .354 & .393 & .293 & .008 & .263 & -.165 & -.106 \\
\hline 4. Avg Minutes per Day of Pornography Use & 10.65 & 22.33 & & & & - & .201 & .161 & .018 & .144 & -.041 & -.006 \\
\hline 5. "I am addicted to Internet pornography." & 2.07 & 1.62 & & & & & - & .694 & .489 & .844 & .319 & .205 \\
\hline $\begin{array}{l}\text { 6. "I have put off things I needed to do in } \\
\text { order to view pornography." }\end{array}$ & 2.09 & 1.66 & & & & & & - & .585 & .887 & .348 & .194 \\
\hline $\begin{array}{l}\text { 7. "I feel depressed after viewing } \\
\text { pornography." }\end{array}$ & 2.49 & 1.80 & & & & & & & - & .824 & .618 & .317 \\
\hline 8. Three Item Self-Reported Addiction & 2.22 & 1.44 & & & & & & & & - & .511 & .283 \\
\hline 9. Moral Incongruence & 3.02 & 1.97 & & & & & & & & & - & .447 \\
\hline 10. Religiousness & 4.10 & 1.95 & & & & & & & & & & - \\
\hline
\end{tabular}

**This manuscript is an author pre-print of the same published at The Journal Of Behavioral Addictions. ** 
Grubbs et al., (2018); Journal of Behavioral Addictions, DOI: 10.1556/2006.7.2018.134

Table 2

Gender breakdown for item response distributions for key variables and mean comparisons on each.

"I believe that pornography use is morally wrong"

$\left(\chi^{2}[6]=18.019, p=.006 ;\right.$ Women $M=3.04, S D=1.97 ;$ Men $\left.M=3.02, S D=1.96 ; t[1459]=0.15, p=.882\right)$

\begin{tabular}{rccccccc} 
& $\begin{array}{c}\text { Strongly } \\
\text { Disagree }\end{array}$ & Disagree & $\begin{array}{c}\text { Somewhat } \\
\text { Disagree }\end{array}$ & $\begin{array}{c}\text { Neither } \\
\text { Agree or } \\
\text { Disagree }\end{array}$ & $\begin{array}{c}\text { Somewhat } \\
\text { Agree }\end{array}$ & Agree & $\begin{array}{c}\text { Strongly } \\
\text { Agree }\end{array}$ \\
\cline { 2 - 8 } Women & $194(32 \%)$ & $111(19 \%)$ & $41(7 \%)$ & $115(19 \%)$ & $59(10 \%)$ & $21(4 \%)$ & $56(9 \%)$ \\
Men & $284(33 \%)$ & $145(17 \%)$ & $90(10 \%)$ & $161(19 \%)$ & $55(6 \%)$ & $57(7 \%)$ & $72(8 \%)$ \\
\cline { 2 - 8 } Total & $478(33 \%)$ & $256(18 \%)$ & $131(9 \%)$ & $276(19 \%)$ & $114(8 \%)$ & $78(5 \%)$ & $128(9 \%)$
\end{tabular}

"I am addicted to pornography"

$\left(\chi^{2}[6]=72.55, p<.001 ;\right.$ Women, $M=1.71, S D=1.37$; Men $\left.M=2.32, S D=1.72 ; t[1459]=7.23, p<.001\right)$

$\begin{array}{lll}\text { N/A } & \text { Somewhat } & \text { Neither } \\ \text { Strongly } & \text { Disagree or }\end{array}$

Disagree

Disagree

Agree or Somewhat

Disagree

Agree

Agree

Strongly

\begin{tabular}{|c|c|c|c|c|c|c|c|}
\hline \multirow[b]{2}{*}{ Women } & Disagree & & & Disagree & & & \\
\hline & $886(84 \%)$ & $68(6 \%)$ & $22(2 \%)$ & $54(5 \%)$ & $8(1 \%)$ & $10(1 \%)$ & $11(1 \%)$ \\
\hline Men & $597(57 \%)$ & $155(15 \%)$ & $60(6 \%)$ & $108(11 \%)$ & $45(4 \%)$ & $36(4 \%)$ & $30(3 \%)$ \\
\hline Total & $1468(70 \%)$ & $223(11 \%)$ & $82(4 \%)$ & $162(8 \%)$ & $53(3 \%)$ & $46(2 \%)$ & $41(2 \%)$ \\
\hline
\end{tabular}

"I have put off things I needed to do to view pornography."

$\left(\chi^{2}[6]=57.789, p<.001\right.$; Women $M=1.74, S D=1.39 ;$ Men $\left.M=2.34, S D=1.78 ; t[1459]=6.78, p<.001\right)$

$\mathrm{N} / \mathrm{A}$

Strongly

Disagree

Neither

\begin{tabular}{rccccccc} 
& $\begin{array}{c}\text { Strongly } \\
\text { Disagree }\end{array}$ & Disagree & $\begin{array}{c}\text { Somewhat } \\
\text { Disagree }\end{array}$ & $\begin{array}{c}\text { Agree or } \\
\text { Disagree }\end{array}$ & $\begin{array}{c}\text { Somewhat } \\
\text { Agree }\end{array}$ & Agree & $\begin{array}{c}\text { Strongly } \\
\text { Agree }\end{array}$ \\
\cline { 2 - 7 } Women & $874(82 \%)$ & $80(8 \%)$ & $17(2 \%)$ & $55(5 \%)$ & $13(1 \%)$ & $8(1 \%)$ & $12(1 \%)$ \\
Men & $597(58 \%)$ & $149(15 \%)$ & $41(4 \%)$ & $97(10 \%)$ & $63(6 \%)$ & $39(4 \%)$ & $30(3 \%)$ \\
\cline { 2 - 8 } Total & $1471(71 \%)$ & $229(11 \%)$ & $58(3 \%)$ & $152(7 \%)$ & $76(4 \%)$ & $47(2 \%)$ & $42(2 \%)$
\end{tabular}

"I feel depressed after viewing pornography"

$\left(\chi^{2}[6]=7.462, p=.280\right.$; Women $M=2.39, S D=1.78$; Men $\left.M=2.55, S D=1.81 ; t[1459]=1.55, p=.120\right)$

\begin{tabular}{rccccccc} 
& $\begin{array}{c}\text { N/A } \\
\text { Strongly } \\
\text { Disagree }\end{array}$ & Disagree & $\begin{array}{c}\text { Somewhat } \\
\text { Disagree }\end{array}$ & $\begin{array}{c}\text { Neither } \\
\text { Agree or } \\
\text { Disagree }\end{array}$ & $\begin{array}{c}\text { Somewhat } \\
\text { Agree }\end{array}$ & Agree & $\begin{array}{c}\text { Strongly } \\
\text { Agree }\end{array}$ \\
\cline { 2 - 8 } Women & $749(71 \%)$ & $109(10 \%)$ & $28(3 \%)$ & $96(9 \%)$ & $34(3 \%)$ & $12(1 \%)$ & $31(3 \%)$ \\
Men & $525(52 \%)$ & $167(16 \%)$ & $56(6 \%)$ & $133(13 \%)$ & $61(6 \%)$ & $29(3 \%)$ & $45(4 \%)$ \\
\cline { 2 - 8 } Total & $1,274(61 \%)$ & $276(13 \%)$ & $84(4 \%)$ & $229(11 \%)$ & $95(5 \%)$ & $41(2 \%)$ & $76(4 \%)$
\end{tabular}

"Within the past year, how often have you viewed pornography?"

$\left(\chi^{2}[7]=149.954, p<.001 ; M=1.71, S D=1.37 ;\right.$ Men $\left.M=2.32, S D=1.72 ; t[1459]=7.23, p<.001\right)$

Two or

three A few Once a

\begin{tabular}{rcccccccc} 
& $\begin{array}{c}\text { N/A } \\
\text { Never }\end{array}$ & $\begin{array}{c}\text { Once or } \\
\text { Twice }\end{array}$ & $\begin{array}{c}\text { A few } \\
\text { times }\end{array}$ & $\begin{array}{c}\text { Once a } \\
\text { month }\end{array}$ & $\begin{array}{c}\text { times a } \\
\text { month }\end{array}$ & $\begin{array}{c}\text { Once a } \\
\text { week }\end{array}$ & $\begin{array}{c}\text { times a } \\
\text { week }\end{array}$ & $\begin{array}{c}\text { day or } \\
\text { more }\end{array}$ \\
\cline { 2 - 9 } Women & $705(67 \%)$ & $99(9 \%)$ & $85(8 \%)$ & $37(3 \%)$ & $52(5 \%)$ & $27(3 \%)$ & $34(3 \%)$ & $20(2 \%)$ \\
Men & $312(30 \%)$ & $98(10 \%)$ & $126(12 \%)$ & $51(5 \%)$ & $97(10 \%)$ & $98(10 \%)$ & $151(15 \%)$ & $83(8 \%)$ \\
\cline { 2 - 10 } Total & $1017(50 \%)$ & $197(9 \%)$ & $211(10 \%)$ & $88(4 \%)$ & $149(7 \%)$ & $125(6 \%)$ & $185(9 \%)$ & $103(5 \%)$ \\
\hline
\end{tabular}

Percentages represent percentage of the total sample $(N=2,075)$, not percentages of pornography users $(n=1,461)$, with the exception of moral incongruences, for which percentages only represent users $(n=1,461)$.

Chi-Square and Independent t-test values represent comparisons among pornography users only $(n=1,461)$

$\mathrm{N} / \mathrm{A}=$ no self-reported exposure to pornography, were not included in questions (462 women, $152 \mathrm{men}$ )

${ }^{* *}$ This manuscript is an author pre-print of the same published at The Journal Of Behavioral Addictions. ** 
Grubbs et al., (2018); Journal of Behavioral Addictions, DOI: 10.1556/2006.7.2018.134

**This manuscript is an author pre-print of the same published at The Journal Of Behavioral Addictions. ** 
Grubbs et al., (2018); Journal of Behavioral Addictions, DOI: 10.1556/2006.7.2018.134

Table 3

Hierarchical Multivariable Regression Predicting Self-Reported Addiction to Internet Pornography

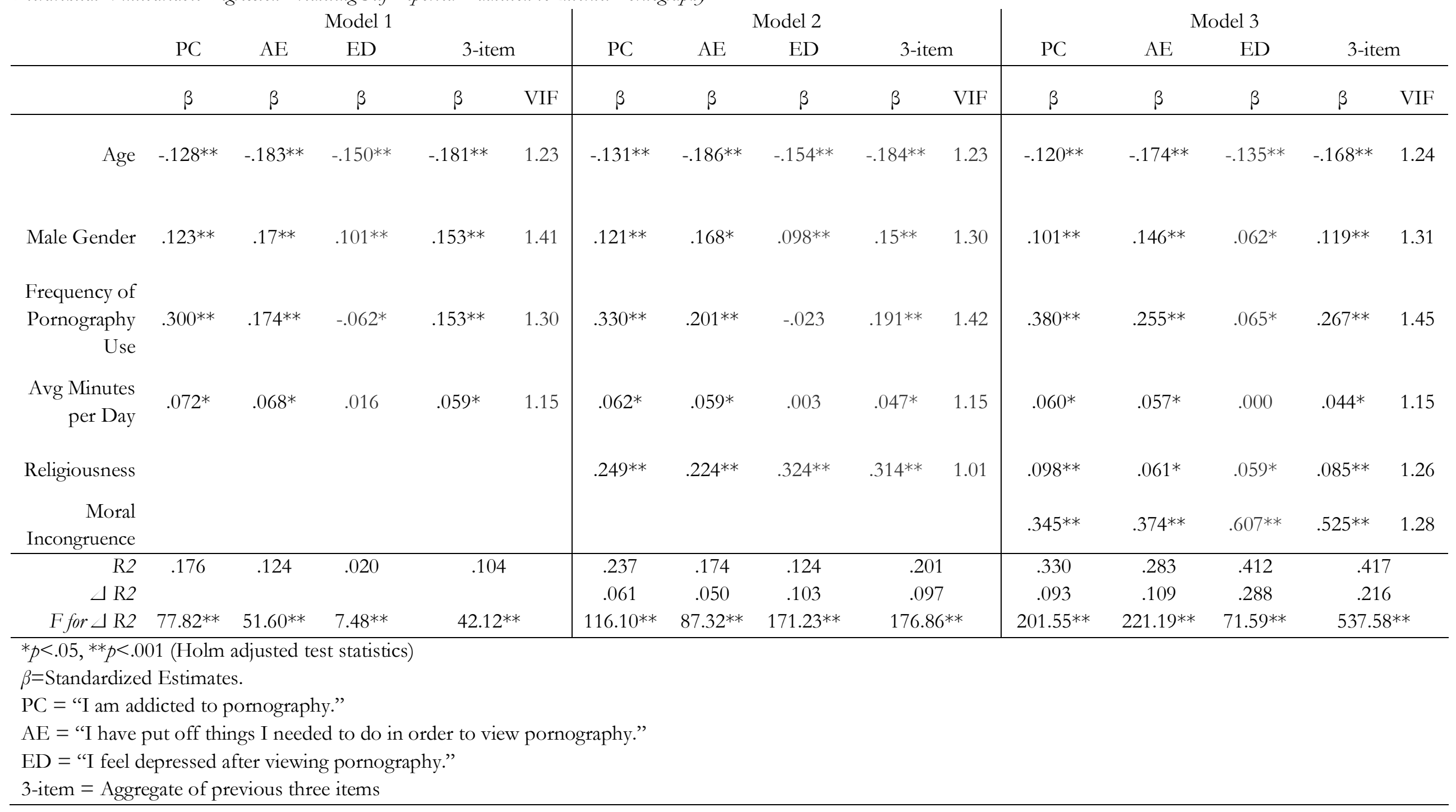

